\title{
Against Constitutional Theory
}

\author{
Paul Campos
}

Nobody can agree on what the Constitution means. Some argue that it prohibits states from banning abortions, ${ }^{1}$ while others claim that it says nothing about abortion, ${ }^{2}$ or that it prohibits abortion. ${ }^{3}$ It is claimed that the Constitution abolishes the death penalty, ${ }^{4}$ and that it specifically authorizes the death penalty; ${ }^{5}$ that it bans segregated schools ${ }^{6}$ and is indifferent to segregation; ${ }^{7}$ that it requires that we exempt religious believers from laws that burden the practice of their religion, ${ }^{8}$ and that it prohibits governments from granting such exemptions;' that it eliminates the possibility of a thirty-one year-old president, ${ }^{10}$ and that it welcomes this possibility. ${ }^{11}$ Such examples, of course, could be greatly multiplied. ${ }^{12}$

Two beliefs about this perplexing document do not appear controversial. All commentators seem to agree that the Constitution is a text, and that understanding it is primarily a matter of deploying the proper theory of textual interpretation. ${ }^{13}$ The purpose of this article is to demonstrate that those beliefs are largely mistaken. I am aware that readers of this text will consider such a claim highly counterintuitive, and perhaps

1. See Roe v. Wade, 410 U.S. 113 (1973).

2. See Webster v. Reproductive Health Services, 492 U.S. 490 (1989) (Scalia, J., concurring)

3. See James Bopp \& Richard Coleson, The Right to Abortion: Anomalous, Absolute and Ripe for Reversal, 3 B.Y.U. J. PUB. L. 181 (1989).

4. See Furman v. Georgia, 408 U.S. 238, 296 (1972) (Brennan, J., concurring).

5. See id. at 465 (Rehnquist, J., dissenting).

6. See Brown v. Board of Education, 347 U.S. 483 (1954).

7. See RAOUl Berger, Government By Judiciary 118-19 (1977).

8. See Sherbert v. Verner, 374 U.S. 398 (1963).

9. See William Marshall, The Case Against the Constitutionally Compelled Free Exercise Exemption, 40 CASE W. RES. L. REv. 357 (1990); compare Employment Div., Dep't of Human Resources v. Smith, 110 S. Ct. 1595 (1990).

10. Richard Fallon, A Constructivist Coherence Theory of Constitutional Interpretation, 100 HARV. L. REV. 1189, 1195 (1987).

11. Gary Peller, The Metaphysics of American Law, 73 CAL. L. REv. 1151, 1174 (1985).

12. See generally Laurence Tribe \& Michael. Dorf, On Reading The Constitution (1991).

13. See Fallon, supra note 10, at 1195: "In one sense, all constitutional arguments-including, for example, arguments concerning precedent and the intent of the framers-are about the text and what it should be held to mean. It is after all, a constitution we are interpreting." $C f$. Michael Perry, The Legitimacy of Particular Conceptions of Constitutional Interpretation, 77 VA. L. REV. 669, 687 (1991) [hereinafter Legitimacy]: "No conception of constitutional interpretation that excluded interpretation of the written text would be taken seriously." 
dismiss it out of hand. I can only prospectively ask for your patience. Reading, Barthes has noted, is an intimacy between strangers; and perhaps, like all intimacy, it requires an initial gesture of faith from both author and reader.

No one can articulate a syllable which is not filled with tenderness and fear, which is not, in some language, the powerful name of a god. ${ }^{14}$

\section{A. A Portrait of the Author as Another Man}

In his story "Pierre Menard, Author of the Quixote" Jorge Luis Borges creates a character whose life goal is to write Don Quixote. Menard's goal is not "to compose another Don Quixote-which would be easy-but the Don Quixote."15 He first considers a straightforward approach:

Know Spanish well, recover the Catholic faith, fight against the

Moors or the Turk, forget the history of Europe between the years 1602 and 1918, be Miguel de Cervantes. ${ }^{16}$.

Menard rejects this method as too easy. For Cervantes at the beginning of the seventeenth century the writing of Don Quixote "was a reasonable ... perhaps even unavoidable"17 undertaking; for Pierre Menard to write the same book in the twentieth century is a considerably more arduous, and therefore, for Menard, more interesting task.

Menard partially succeeds in his absurd enterprise: he finishes two chapters and parts of a third of the famous novel. Borges' narrator notes that despite appearances the two works are not the same. While "Cervantes' text and Menard's are verbally identical [Menard's] is almost infinitely richer." 18 The narrator quotes Cervantes:

truth, whose mother is history, rival of time, depository of deeds, witness of the past, exemplar and advisor to the present, and the future's counselor. ${ }^{19}$

Written in the seventeenth century this is, according to the narrator, "a mere rhetorical praise of history." $20 \mathrm{He}$ then quotes Menard:

truth, whose mother is history, rival of time, depository of deeds,

14. Jorge Luis Borges, The Library of Babel, in LABYRINTHS 51, 57 (1964) [hereinafter Babel]

15. Jorge Luis Borges, Pierre Menard, Author of the Quixote [hereinafter Pierre Menard], in LABYRINTHS, supra note 14 , at $36,39$.

16. Id. at 40 .

17. Id. at 41 .

18. Id. at 43 .

19. Id.

20. Id. 
witness of the past, exemplar and advisor to the present, and the future's counselor. ${ }^{21}$

The narrator is swept away by the contrast:

History, the mother of truth: the idea is astounding. Menard, a contemporary of William James, does not define history as an inquiry into reality but as its origin. Historical truth, for him, is not what has happened, it is what we judge to have happened. . . .

The contrast in style is also vivid. The archaic style of Menardquite foreign, after all-suffers from a certain affectation. Not so that of his forerunner, who handles with ease the current Spanish of his time. ${ }^{22}$

The narrator concludes that Menard has created a new technique to enrich "the halting and rudimentary art of reading."

This new technique is that of the deliberate anachronism and the erroneous attribution. ... This technique fills the most placid works with adventure. To attribute the Imitatio Christi to Louis Ferdinand Celine or to James Joyce, is this not a sufficient renovation of its tenuous spiritual indications? ? $^{23}$

Borges demonstrates that it is possible for the same words to comprise two radically different texts. What is it that allows this phenomenon to take place? The short answer is captured by the word "context": the context within which we read Menard's Quixote is utterly dissimilar from that which we bring to Cervantes' verbally identical text. But what is context but another way of saying authorship? I will argue that to read a text is to try to determine what its author intends to say, and that any other description of textual interpretation is incoherent. ${ }^{24}$ I will claim

21. Id.

22. Id.

23. Id. at 44 .

24. The definition of textual interpretation put forward in this article is essentially that advocated by Steven Knapp and Walter Benn Michaels. See Steven Knapp \& Walter Benn Michaels, Against Theory, 8 CrITICAL INQuiRy 723 (1982); see also Steven Knapp \& Walter Benn Michaels, A Reply to Our Critics, 9 CrITICAL INQUIRY 790 (1983); Steven Knapp \& Walter Benn Michaels, A Reply to Richerd Rorty: What is Pragmatism?, 11 CRITICAL INQUIRY 466 (1985); Steven Knapp \& Walter Benn Michaels, Against Theory 2: Hermeneutics and Deconstruction, 14 CRITICAL INQUiRy 49 (1987). The first three essays are reprinted in Against ThEORY: Literary Studies AND The New Pragmatism (W.J.T. Mitchell ed., 1985). Other relevant texts include: Walter Benn Michaels, Against Formalism: The Autonomous Text in Legal and Literary Interpretation, 1 PoETICS TODAY 23 (1979); Steven Knapp \& Walter Benn Michaels, Intention, Identity, and The Constitution: $A$ Response to David Hoy, in LEGAL HERMENEuTICS: History, Theory, AND Practice (Gregory Leyh ed., 1991); and Steven Knapp, Practice, Purpose, and Interpretive Controversy (forthcoming).

The relationship between intention and meaning is a subject of considerable controversy among philosophers of language. A discussion of that controversy is far beyond the scope of this article, but readers who wish to pursue the subject might begin by consulting THE LINGUISTIC TURN (Richard Rorty ed., 1975), an excellent anthology that delves at length into this and related topics, and provides copious bibliographical references for those who wish to familiarize themselves with the contemporary debate. 
further that this conclusion suggests that theories of interpretation (that is, general accounts of how one goes about getting good interpretations) are therefore pointless and should be abandoned. I will then suggest that these conclusions have, at least in any strong sense, no obvious normative implications for the project of legal, and specifically constitutional, interpretation.

\section{B. How to Do Things with Words}

One way of seeing why reading a text must mean trying to determine what its author intends to say is by attempting to imagine how one would go about reading a text without reference to authorial intention. Suppose you were walking along a trail on a dusty plateau near the border of Arizona and Mexico. You notice that, etched in dust by the edge of the trail, there appear to be four letters which seem to form the word "real." A resident of the area who is with you explains that marks which appear to be words often show up near this part of the trail. Some people, she explains, believe that the desert winds swirl in a way that creates such marks; others believe that someone surreptitiously makes the marks in the sand. ${ }^{25}$

It is clear that your attitude toward this "text" will be a product of the assumptions you make about its authorship. If you believe that the marks are a product of the desert wind, you will conclude that what looked like a word was not a word at all: the marks merely resembled a word. ${ }^{26}$ On the other hand, if you believe some person has traced the marks in the sand, you will ask what the word they form means. Under the circumstances you might wonder whether you were reading the English word "real" or the Spanish word "real" (royal). But this question is in fact meaningless unless it refers to what the author of the word meant, at the elementary level of determining what language the author meant to employ.

Several objections to this account of textual meaning come immediately to mind: doesn't a mark that only appears to be a text become a text when we treat it as such, and can't we still read a text even if we make mistaken assumptions about authorial intention? Furthermore, even if we think we know what the author meant, can't we consciously choose to substitute our own "reading" of the text?

Suppose that you become convinced that the marks in the sand were produced by random fluctuations of the desert wind. If you still insist that the wind has created a "real" word, you can only do so by adhering to one of two positions. Either you believe in an extreme combination of

25. This example is a variation on the "wave poem" illustration used by Knapp and Michaels in Against Theory, supra note 24.

26. Unless you believe the desert wind is controlled by a sentient being, in which case the marks could represent a speech act. 
linguistic formalism and epistemological and ontological realism that simultaneously denies the conventional nature of semantic meaning and affirms our access to an absolute world order, ${ }^{27}$ or you can claim, in the alternative, that even if the marks were initially meaningless, they now have a meaning for you. Few would be willing to admit to the former position, while the latter claim merely confuses the issue. For if the marks were initially meaningless, but have become meaningful through your ascription of meaning to them, then it is precisely through that ascription that they have become a text: a text of which you are the author.

In the alternative, suppose that you assumed that the marks were made by an English speaker who intended by the word "real" the opposite of imaginary. You later discover that in fact the marks were made by a Spanish speaker who meant by "real" roughly what an English speaker would usually mean by "royal." Wasn't your initial assumption a reading? Yes it was, but it was a particular type of reading: a misreading, by which you misunderstood what the author actually said. Misreading is always possible, but it neither alters the text's meaning or our relation to it.

Or imagine that you subsequently discover that the marks were made by a monolingual English speaker, but because of an aesthetic preference (you think the Spanish word is prettier), or a political longing (you would prefer the text to be the work of a cryptic monarchist), you choose to treat the marks as if they comprised a Spanish word. Of course this is a perfectly possible procedure. I will call this sort of conscious disregard of the author's text reauthoring. This is exactly the procedure that Pierre Menard revealed through his reauthoring of Don Quixote, the technique

27. Michael Moore presents an elaborate defense of such an account of linguistic meaning in $A$ Natural Law Theory of Interpretation, 58 S. CAL. L. REV. 277 (1985). Moore's account of linguistic meaning depends entirely upon the distinction, common in speech act theory, between the meaning of an utterance and the meaning of the sentence within which that utterance is encoded. He defines sentence meaning as "the meaning [a] type of utterance has, abstracted from any particular occasion of utterance." He asks us to imagine receiving a one-sentence anonymous letter " "with no clue whatsoever about the motive, circumstances of transmission, or any other factor relevant to understanding the sentence on the basis of its context of utterance." (Quoting JERROLD KATZ, Propositional Structure and Illocutionary Force 14 (1980)) (emphasis added). The sentence meaning of the letter is defined as what we know about the letter's meaning "in such a contextless situation." The utterance meaning is the meaning that context adds to the sentence meaning. The problem with this account is that it assumes there can be such a thing as contextless meaning. Moore's own example decisively refutes this assumption. It involves an epistemological absurdity to assert that one could receive a one-sentence letter that contained no information "relevant to understanding the sentence on the basis of its context of utterance." For how would the recipient of this letter know 1) that it was a letter, 2) that it contained words, as opposed to marks that resembled words, and 3) that the words were those of a particular language, in sum, that these marks were an instance of an intention to undertake semantic communication, unless the reader brought a considerable number of assumptions about the context of utterance-about the author's intentions--into her reading? And all this information-in fact all the reader's conclusions about the text's meaning — depend upon the assumptions she must necessarily make about "the context of utterance." As Stanley Fish has demonstrated, the idea of a contextless sentence always involves a contradiction in terms. See Stanley Fish, Is There a TeXt in This Class? 269-92 (1980). 
of "deliberate anachronism and erroneous attribution [that] fills the most placid works with adventure." 28

If this account of textual interpretation is correct, then a text always means what its author intends, and a reading of a text must perforce be an attempt to discover that intention. We have seen that it is possible to do things with words, other than read them: we can misread them (by incorrectly understanding the author's meaning), we can write with them (ascribing the meaning we choose to words without reference to another author), or we can reauthor them (consciously ignoring what we know about the author's-and hence the text's-meaning in favor of our preferred understanding of the words he or she employed).

Although there is little or no theoretical difference between writing and reauthoring, a critical distinction does exist, as a matter of social practice, between the two methods: in our culture only reauthoring can successfully claim to be a form of textual interpretation. ${ }^{29}$

It is important to emphasize that this is not a methodological, let alone a normative, ${ }^{30}$ prescription for how one should read texts. To imagine that one should read a text so as to discover what its author intended by it is to mistakenly assume that it is possible to do anything else. But since any reading of a text which really is a reading of that text simply consists of a search for authorial intention, statements such as, "The supreme court ... should have accorded interpretive primacy to original intent in ascertaining the 'meaning' of the constitution,"31 if they are statements about the Constitution as a text, are both tautological and methodologically empty.

The fact that similar claims are routinely made by theorists of all persuasions, either fervently demanding, ${ }^{32}$ or cautiously recommending, ${ }^{33}$ or openly deploring, ${ }^{34}$ the use of authorial intention as a tool for ascertaining the meaning of the constitutional text, helps locate the main source of

28. See Borges, Pierre Menard, supra note 15 , at 44.

29. This is not universally the case. For instance, among certain Ural-Altaic groups

[t]he concept of plagiarism does not exist: It has been established that all works are the creation of one author, who is atemporal and anonymous. [Their] critics often invent authors: they select two dissimilar works-the Tao Te Ching and the 1001 Nights, say-attribute them to the same writer, and then determine most scrupulously the psychology of this interesting homme de lettres. ... .

A First Encyclopaedia of Tlön, 919 (1944).

30. The tendency of legal academics to immediately translate everything into a series of normative prescriptions has recently been explored by Pierre Schlag. See Pierre Schlag, Normativity and the Politics of Form, 139 U. PA. L. ReV. 801 (1991); Pierre Schlag, "Le Hors de Texte, C'est Moi": The Politics of Form and the Domestication of Deconstruction, 11 CARDozo L. REV. 1631 (1990); Pierre Schlag, Normative and Nowhere to Go, 43 STAN. L. REV. 167 (1990).

31. Henry Monaghan, Our Perfect Constitution, 56 N.Y.U. L. REV. 353, 375 (1981).

32. See BERGER, supra note 7, at 153-55.

33. See Michael Perry, The Authority of Text, Tradition, and Reason: A Theory of Constitutional "Interpretation", 58 S. CAL. L. REV. 551 (1985) [hereinafter Authority].

34. See generally Mark Tushnet, Red, White, and Blue: A Critical analysis of Constitutional. LaW (1988). 
confusion which envelops contemporary debates on constitutional interpretation. This confusion arises because we imagine that intention is something one either does or does not add to a reading of a text in order to extract a meaning from it. Once one sees, however, that meaning and intention are not separable, and are in fact identical, ${ }^{35}$ appeals to authorial intention, whether celebratory or condemnatory, lose most of their force and interest.

The question then becomes: should we read the Constitution or should we do something else with it?

I know of an uncouth region whose librarians repudiate the vain and superstitious custom of finding a meaning in books and equate it with that of finding a meaning in dreams or in the chaotic lines of one's palm. ... This dictum, we shall see, is not entirely fallacious. ${ }^{36}$

Utopia Park is the pride of Erehwon. Its many winding paths are frequented by joggers, bicyclists, and those townspeople who simply want to take a leisurely stroll. Recently, many pedestrians have complained that certain bicyclists ride down the paths at dangerous speeds and reduce the tranquility of the park. Matters came to a head last week when a collision with a fast-moving bike put an eight-year-old girl in the hospital with a broken wrist. Two nights later, the girl's parents appeared at a town council meeting and angrily demanded that the council ban bicycles from the park. They pointed to an ordinance passed by the council nearly thirty years ago which stated "No vehicles shall be permitted in the park," and claimed that this ordinance prohibited bicycles from entering the park. Several other opponents of bicycles in the park voiced their agreement and insisted that the council enforce the law. The council's three members, Henry, Michael, and Ronald, promised to answer these demands at the next council meeting, after they had had a chance to give the matter further study. The night before the meeting they gathered in the basement of the local Unitarian church to discuss their conclusions.

\section{A. Three Scholars in Search of a Gavel}

Michael: I've brought some doughnuts.

Henry: How thoughtful. Ah, glazed. Ronald?

Ronald: No thanks. I prefer coconut macaroons.

35. That is, semantic intention and semantic meaning are identical. As Knapp and Michaels point out, "[n]ot all intentions are intentions to mean (not all acts are speech acts)." Knapp \& Michaels, Against Theory 2, supra note 24, at 49.

36. Borges, Babel, supra note 14 , at 53 . 
Michael: Of course. Now it seems to me that we are already in agreement on a couple of fundamental points.

Ronald: Such as?

Michael: First, bicyclists are extremely important to Erehwon. Because of the mountains and climate, this is an ideal spot for professional bicyclists to train. Counting both professional Tour rides and triathletes, we have at least a dozen world-class competitors living in this area. We have a chance to get the national Olympic training center moved here sometime in the next few years. I don't have to tell you what that would mean for the local economy.

Henry: All right, we all agree that's an important consideration. What's your other point?

Michael: We have to do the right thing. We can't just interpret this ordinance to mean whatever we need it to mean-we have to interpret it properly. If we don't remain within the boundaries of the text's meaning, we will set a precedent that could lead to lawless tyranny on the town council.

Henry: Or anarchy.

Ronald: Or nihilism.

Michael: So the question is, can we honestly properly interpret the ordinance and keep the bicyclists in town?

Ronald: That sounds right to me.

Henry: Michael, you've looked into the history of this ordinance. What did you find out?

Michael: The ordinance was passed on November 11, 1963 by a 2 to 1 vote. Council members James and Lawrence voted in favor; Conrad voted against. The council minutes reveal that the ordinance was passed primarily to keep motorcycles out of the park.

Ronald: Good enough. Our interpretive problem is solved.

Michael: Unfortunately, I don't think it is. The council debated how broadly the term "vehicle" should be defined. James stated that it should mean anything that could move fast enough to harm a pedestrian. Someone in the audience asked whether that included bicycles; James and Lawrence thought it should, while Conrad subsequently refused to vote for the ordinance because he didn't think bicycles should be banned from the park.

Henry: So why hasn't the ordinance been enforced?

Michael: It was enforced, for a few years. But by 1970 the composition of the council had changed: the new members weren't willing to exclude bicycles from the park.

Henry: Why didn't they revise the ordinance?

Michael: Perhaps they thought it was unnecessary.

Ronald: Exactly. Why should they have revised it? It's perfectly possible to read the ordinance so as to allow bicycles. 
Henry: But that's not how it was written.

Ronald: What difference does that make to us?

Michael: Before we debate the merits of this question, let me just bring us up to the present. The ordinance has never been revised, but as far as I could discover, no one has been cited for riding a bike in Utopia Park since 1971. I'm sure very few people remembered it was once prohibited.

Henry: Isn't it still prohibited?

Ronald: Come on, hundreds of people ride their bicycles in the park every day: some of these athletes train there. What possible point could there be to announcing at this late date that what they're doing is illegal? I thought we all agreed that bicycling is very important to Erehwon's future. We need to convince people that the best interpretation of the ordinance will allow bicycles in the park. Now how are we going to do that?

The council members argued among themselves far into the night. By the next day they had each developed a distinctive interpretive strategy which would allow the council to announce that, under the existing ordinance, bicycles were allowed in the park.

\section{B. Against Interpretation}

Henry's argument was comparatively straightforward. For Henry, it was simply nonsensical to claim that the ordinance could be interpreted so as to allow bicyclists in the park. The authors of the ordinance had considered and rejected that possibility. However, he reasoned that if a text cannot be interpreted in a manner which generated the result desired by the interpreter, an interpretive (or one might say an anti-interpretive) option remains: the reader can choose to ignore the text.

Henry argued that although it was absurd to imagine that the ordinance permitted bicycles in the park, it would be even more ridiculous to enforce the ordinance at this time. The customs, practices, and recent history of Erehwon all argued against such a result. Everyone now assumed that one could bring bicycles into Utopia Park. Enforcing the ordinance would not only damage the economic future of Erehwon, it would upset a well-settled group of expectations that the community had developed and relied upon. For Henry the answer to the interpretive problem was simple: if an aspect of the meaning of the ordinance had become fundamentally unacceptable to the community, then the community should refuse to enforce that aspect.

\section{Systematic Misreading}

Michael found Henry's solution elegant but unacceptable. He believed that to refuse to enforce the ordinance was a form of public dereliction 
which could eventually undermine the rule of law. For Michael, it was necessary to enforce the true meaning of the ordinance in such a way as to continue to allow bicycles into the park.

Michael reasoned that although the authors of the ordinance had specifically intended to ban bicycles from the park, this specific intention was not the product of an arbitrary impulse, but had been generated by a more general intention: to ban those vehicles from the park that unreasonably endangered pedestrians and other persons who chose to enjoy the park's facilities. Michael argued that in order to enforce the original meaning of the ordinance properly, the council had to honor this more general intention of the law's authors. He claimed that if James and Lawrence were confronted with Erehwon's present economic and social condition, they would agree (given the benefits that bicycles might bring to Erehwon, as well as the citizenry's customary use of bicycles in Utopia Park) that bicycles did not pose an unreasonable hazard to other persons in the park.

But Michael's interpretive strategy contained an even more audacious claim: he held that even if James and Lawrence were to disagree with the present council members on the reasonableness of bicycles in Utopia Park, it was up to the present council to determine what the most accurate understanding of James' and Lawrence's general intention was. James and Lawrence had intended to ban unreasonably dangerous vehicles from the park, and the council was bound by the rule of law to follow that intention. It remained, however, the duty of the present council-and only the present council-to determine what the best present understanding of that general intention entailed.

By deploying the proper interpretive method, Michael claimed, the council could simultaneously enforce the original meaning of the ordinance and address those problems generated by the ever-changing context of the present interpretive moment.

\section{Reauthoring}

Ronald rejected the approaches of both of his colleagues. While Henry seemed willing to abandon all hope of rehabilitating the ordinance, and Michael appeared obsessed with producing an interpretation that could be characterized as faithful to the ordinance's original meaning, Ronald's concerns were somewhat different. He was just as convinced as his fellow council members of the desirability of permitting bicycles in Utopia Park, but in contrast to Henry's pragmatic approach and Michael's concern with historical integrity, Ronald wanted to generate a justification that would be, for lack of a better phrase, aesthetically pleasing.

To that effect, he argued that the ordinance should be treated not as evidence of a singular political event (i.e., the council vote of November 
$11,1963)$ but as a textual object whose meaning changed over time. The goal of the object's interpreters should be guided by a political aesthetic to make the ordinance the best ordinance it could be within the genre of political events to which it belonged. Ronald stressed that the council members were far from wholly unconstrained in this task: they were limited by the language of the ordinance itself and by the political history of its interpretation. For instance, if the ordinance had happened to say "No bicycles are permitted in the park," or if the ordinance had been consistently understood by everyone to forbid bicycles, it would be diffcult to generate the necessary interpretive "fit" for an argument that claimed the ordinance actually allowed bicycles in the park.

The language of the ordinance, however, was providentially ambiguous, and nothing in its interpretive history precluded the reading that they all longed to justify. Everyone on the council agreed that the most desirable understanding of the ordinance would permit bicycles in the park; Ronald argued that his strategy of interpretation would allow the ordinance to fulfill its potential as a legal object. The text could be interpreted in a plausible and aesthetically pleasing manner and still achieve the social goals that were the object of the genre of textual objects to which it belonged.

\section{III}

A blasphemous sect suggested that the searches should cease and that all men should juggle letters and symbols until they constructed, by an improbable gift of chance, these canonical books. ${ }^{37}$

The foregoing arguments will no doubt seem familiar to those acquainted with recent disputes concerning constitutional interpretation. It is a field in which a classic interpretive conundrum is repeated over and over again: the text of the document generates a result which, in terms of contemporary law and politics, seems wholly unacceptable.

I will now discuss in a less oblique manner three grand strategies designed to deal with the constitutional text in such situations. These strategies, or some variation on them, make up a broad, though not exhaustive, typology of modern constitutional argument. As will become clear, two unifying characteristics link the three methods: all of them demand that we obey the Constitution and none of them recommend that we read the constitutional text.

\section{A. The Pragmatic Reader}

Henry Monaghan is the perfect originalist. His acerbic observations on the utopian arrogance of legal scholars hit too close to home and were

37. Id. at 55-56. 
naturally dismissed, ${ }^{38}$ but his suggestion that the Constitution itself might be the product of human beings remains a troubling thesis. ${ }^{39}$

Monaghan effectively criticizes theories of constitutional interpretation which obscure or deviate from the idea that the meaning of the constitutional text is inseparable from the intentions of those who wrote it. ${ }^{40} \mathrm{He}$ is then faced with a sharp dilemma, and the challenge that arises as a consequence of it. Monaghan admits that the meaning of the constitutional text cannot be reconciled with much of modern constitutional law. ${ }^{41} \mathrm{He}$ acknowledges the validity of Paul Brest's claim that, at a minimum, all decisions which apply aspects of the Bill of Rights to the states, as well as the whole line of "right to privacy" cases and virtually all recent First Amendment decisions, are inconsistent with an accurate reading of the constitutional text. ${ }^{42}$

This situation leaves Professor Monaghan with a major interpretive problem. He rejects out of hand Brest's elegant solution:

Why [Brest] asks, should the constitutional text be authoritative at all for successor generations? It is, I recognize, logically possible to maintain some ground other than the written constitution as the first principle in constitutional theorizing; but I simply find this argument to be a barren one. . . For the purposes of legal reasoning, the binding quality of the constitutional text is incapable of and not in need of further demonstration. ${ }^{43}$

Monaghan treats as axiomatic the assertion that "the body politic can at a specific point in time [i.e., by encoding its will in a text] definitely order relationships, and that such an ordering is binding on all organs of government until changed by amendment." 44 This is, for him, the essence of a written constitution. Monaghan's dilemma, then, is a sharp one. He recognizes that reading a text means trying to determine what its author(s) intended to say, and that it is a fundamental claim of our legal rhetoric that the text of the Constitution is binding law on all branches of government. Enforcing an accurate reading of the constitutional text, however, would inevitably result in a massive destabilization of constitutional law, since such a reading would necessarily overrule a substantial portion of modern constitutional doctrine. ${ }^{45}$ Yet if constitutional law cannot tolerate engagement with the constitutional text because of the state of constitutional doctrine, exactly what role is the word "constitu-

38. See Perry, Authority, supra note 33 , at 568.

39. See Sanford Levinson, Law as Literature, 60 TEX. L. REV. 373, 379 (1982).

40. See Monaghan, Our Perfect Constitution, supra note 31, at 374-77.

41. Id. at 381-82.

42. Id.

43. Id. at $383-84$.

44. Id. at 376 .

45. Id. at 382 . 
tional" playing in this sentence? Monaghan's answer would no doubt be: certainly not one that is semantically coherent or politically edifying.

His own suggestions on how best to solve the dilemma remain tentative. Although he explicitly rejects Brest's proposal that we ignore the constitutional text when it seems prudent to do so, ${ }^{46}$ Monaghan's interpretive strategy is difficult to distinguish from the program of his colleague:

The expectations so long generated by this body of constitutional law render unacceptable a full return to original intent theory in any pure, unalloyed form. While original intent may constitute the starting point for constitutional interpretation, it cannot now be recognized as the only legitimate mode of constitutional reasoning. To my mind, some theory of stare decisis is necessary to confine its reach. Of course, this is to accord an authoritative status to tradition in "supplementing or derogating from" the constitutional text. . . . .

Monaghan concedes the great difficulties inherent in formulating such a theory, ${ }^{48}$ but stops short of admitting that there would be little practical difference between it and Brest's "general, nontextual mode of constitutional analysis." 49 In point of fact, the only real difference between the two theorists' approaches seems to be how much bike riding would have to take place in the park before each would declare the relevant ordinance irrelevant. ${ }^{\text {so }}$

When it deals with the classic conundrum of the unacceptable constitutional text, original intent theory-even in Monaghan's strongly stated form-reverts to a kind of pragmatic anti-interpretation that has much in common with just those versions of constitutional theory that it finds most unacceptable. ${ }^{51}$ When reading the constitutional text will not do, then ignore it: this radical idea is elegant and descriptively satisfying, but it fails to address precisely those concerns about judicial legitimacy that Monaghan identifies as the most compelling reasons for reading the Constitution, rather than doing something else with it.

\section{B. The Systematic Misreader}

Michael Perry claims to solve Henry Monaghan's dilemma for him.

46. See Paul Brest, The Misconceived Quest for the Original Understanding, 60 B.U. L. REV. 204 (1980).

47. Monaghan, Our Perfect Constitution, supra note 31, at 382.

48. See Henry Monaghan, Stare Decisis and Constitutional Adjudication, 88 Colum. L. Rev. 723, 767-72 (1988).

49. Monaghan, Our Perfect Constitution, supra note 31, at 382.

50. Brest in fact uses the example of a statute declaring "no vehicles will be allowed in the park" to demonstrate the undesirability of enforcing the constitutional text in many situations. See Brest, supra note 46 , at $209-13$.

51. Even Raoul Berger concedes as much, despite his polemics against the jurisprudence of the Fourteenth Amendment. See BERGER, supra note 7, at 411-14. 
Since Perry's solution involves asserting that Monaghan does not exist, the latter may be forgiven if he is less than impressed with the former's proof. ${ }^{52}$

Perry advocates "sophisticated originalism." 53 His interpretive strategy makes the following assertions: 1) A judge should enforce a constitutional provision according to its original meaning; 2) The meaning of a provision may have relatively specific aspects and a relatively general aspect; 3) Enforcing a provision means enforcing both the specific and the general aspects of that meaning. ${ }^{54}$

Perry uses the Equal Protection Clause of the Fourteenth Amendment for illustrative purposes. He asks us to assume that a specific aspect of the meaning of the clause is that no state may discriminate on the basis of race, and that:

The most general aspect of the original meaning-the broadest articulation of the most general aspect warranted by the relevant materials-is that no state may discriminate on the basis of "irrational prejudice." Assume also, however, that it is not a specific aspect of the original meaning of the equal protection clause that no state may discriminate on the basis of sex. . . . Given those assumptions, originalism authorizes a judge to enforce, in the name of the equal protection clause, not only the (relatively) specific principle that no state may discriminate on the basis of race, but also the (relatively) general principle that no state may discriminate on the basis of irrational prejudice. ${ }^{55}$

It makes no difference, according to Perry, whether or not the authors of the Fourteenth Amendment thought gender discrimination was a form of discrimination based on irrational prejudice. Perry admits that in all likelihood they did not. What matters is the underlying principle:

[That the ratifiers] did not believe that they were prohibiting a practice does not mean that the correct application of a principle they established does not prohibit the practice. ${ }^{56}$

The specific/general, narrow/broad, concept/conception move is an extremely common one in constitutional interpretation. ${ }^{57}$ Monaghan's dilemma is solved by specifying authorial intent at whatever level of generality is necessary to overcome the embarrassing implications of the text. This method allows the interpreter to discover that even if the authors of the Constitution specifically intended to allow a practice, the

52. See infra note 72 and accompanying text.

53. Perry, Legitimacy, supra note 13 , at 681 . Few theorists explicitly advocate "unsophisticated originalism."

54. Id. at $695-96$.

55. Id. at 696 .

56. Id. at 701 .

57. The move gained its initial impetus from the earlier work of Ronald Dworkin. See RoNALD Dworkin, TAking Rights Seriously 134-36 (1977). 
general principle from which they derived their specific intention might in fact prohibit that practice. ${ }^{58}$ For instance, in the context of the Eighth Amendment Perry argues for the possibility that the death penalty "is truly a cruel or unusual punishment-notwithstanding that the ratifiers of the clause did not so believe." 59 I do not intend to offer a full scale critique of Perry's interpretive account. Instead, I will argue that he cannot accurately be characterized as an advocate of reading the constitutional text when faced with the classic interpretive conundrum.

Perry claims that his brand of originalism is "elaborated entirely without reference to authorial intentions" (his emphasis). ${ }^{60}$ This claim, of course, could not in a logical sense be strictly true: even if Perry's method actually advocated ignoring authorial intent (which it does not) such a method would still refer to the author(s), if only in an oppositional or dismissive manner. But Perry does not advocate ignoring authorial intent; he advocates discovering a dichotomy between the author's general intent and his or her specific intent, and then systematically privileging the former over the latter. ${ }^{61}$

The distinction between specific and general intent is not completely empty. Take the question of cruel punishments: if I enact a statute barring cruel punishments, I might or might not consider capital punishment cruel. Suppose I do not think it is cruel. It is clear that when I said "cruel punishments," then, I did not mean capital punishment. My general category of cruel punishments did not include the specific example of capital punishment. Now suppose I later change my mind: I come to believe that the death penalty is cruel. Has the meaning of the statute that I enacted changed? Clearly not: at the time, I used the general term cruel to capture a set of specific practices which didn't include capital punishment; now, if I were to use the term, it would include capital punishment. What has changed is what I now mean by "cruel," not what I then meant by "cruel." 62

But even if I were to concede, for the purpose of argument, that by

58. See supra text accompanying note 55 .

59. Perry, Legitimacy, supra note 13 , at 701 .

60. Id. at 682 . Cf. Hemingway on the modern bullfight: "It is a decadent art in every way and like most decadent things it reaches its fullest flower at its rottenest point, which is the present." ERnest Hemingway, Death in THE AFTERnoOn 68 (1932).

61. "In that sense and to that extent, the present meaning - the present authoritative meaningof the [Constitution] is different from the original meaning." Perry, Legitimacy, supra note 13, at 697.

62. A moral realist such as Michael Moore would argue that the meaning of the statute had not changed. Moore would claim that the word "cruel" refers to certain practices that are objectively cruel, whether we believe them to be cruel or not. If capital punishment is "really" cruel, then my statute always banned capital punishment, whether I thought it did or not. By using the word "cruel," I refer to the actual meaning of cruelty, not to my (possibly mistaken) conception of what is cruel. See generally Moore, supra note 27. Perry, on the other hand, seems to opt for the "deep conventionalism" advocated by Dworkin. According to this view, what gives the word "cruel" meaning is the interpreter's best estimate of what "it" means. Note how the ontological status of words becomes extremely fuzzy in the Dworkin/Perry world of concepts/conceptions and general/ 
changing my mind about cruelty I have somehow changed the meaning of the statute I previously enacted, this does not affect Perry's argument at all. For Perry, what counts is not what the text means by "cruel," or even what the author now thinks is cruel, but rather, what the interpreter thinks would comprise the best elucidation of the general principle that the author was invoking. ${ }^{63}$

To see why this is so, we can examine Perry's description of four varieties of originalism in the context of capital punishment and the Eighth Amendment. Perry presents three possible situations. In situation one, the authors of the Eighth Amendment intended (or would have intended if they had considered the issue) the Eighth Amendment to prohibit the death penalty. ${ }^{64}$ In situation two, the authors did not intend the Eighth Amendment to prohibit the death penalty because they never considered the possibility, and if they had considered the possibility they would have been uncertain as to whether or not it did (i.e., as far as its authors were concerned, the Eighth Amendment had nothing to say about the death penalty). ${ }^{65}$ In situation three, the authors intended, or would have intended had they considered the issue, for the Eighth Amendment not to prohibit the death penalty. ${ }^{66}$

Perry then identifies what he considers the "four basic versions of originalism." (1) In the strictest version of the theory, a court should invalidate capital punishment only in situation one ${ }^{67}$ (2) A less strict version would allow a court to invalidate capital punishment in either situation one or situation two if the court believes capital punishment violates the general principles which underlay the specific intentions of the Eighth Amendment's authors. ${ }^{68}$ (3) An even looser version of originalism would allow a court to invalidate capital punishment in either situation one, situation two, or situation three if the court concludes that it violates the general principles behind the author's intentions. ${ }^{69}$ (4) The least strict version of originalism is identical to the third version, except that in this manifestation, a court would not invalidate capital punishment even in situation one if the court concluded that capital punishment did not violate the general principle underlying the author's specific intentions. ${ }^{70}$ According to this version, it would be perfectly legitimate

specific meanings. To a pragmatic conventionalist a word means what its author means by it. To a realist, a word refers to some absolute reality of the signified, to what is "really" cruel.

It is very unclear what, if anything, the words of an author (as opposed to the words of the author's reader) refer to in Perry's and Dworkin's accounts of linguistic meaning.

63. Perry, Legitimacy, supra note 13, at 697.

64. Id. at 708 .

65. Id.

66. Id.

67. Id. at 708-09.

68. Id. at 709 .

69. Id.

70. Id. 
for a judge to hold that the Eighth Amendment permitted drawing and quartering, even though the authors of the amendment specifically intended to prohibit that practice-if the judge believes that drawing and quartering is not inconsistent with the relevant general principle. ${ }^{71}$

Perry asserts that it "is difficult to identify originalists today who defend the first version of originalism, or even the second version," claims that even Robert Bork's latest elaboration of originalist theory rejects the first two versions and "seems underdeterminate with respect to the choice between the third and fourth versions." 73 As for Perry himself, he is mildly inclined towards the third version, but he suspects that in terms of actual political consequences "the difference between the third and fourth versions probably is not great." 74

I suspect that Perry is correct. An account of originalism that allows us to "read" an amendment so as to prohibit capital punishment, even though the authors of that amendment intended to allow the death penalty, will not differ significantly in its actual consequences from an interpretive account that allows us to "read" the amendment in a less prohibitory fashion than the authors intended. Either method is flexible enough to solve interpretive conundrums that, after all, only arise because of the constraints of authorial (i.e., textual) meaning.

We can easily understand the attractiveness of "sophisticated" or "moderate" originalism. It is a strategy which allows the interpreter to claim that he or she is interpreting the author's text and no other, and yet at the same time to generate readings that are in direct opposition to the author's meaning. It allows us to combine, in a way that Monaghan's approach does not, ancestor worship with pragmatic politics, and to practice "interpretation" as a form of textual rehabilitation.

But if a text means only what its author intends it to mean-no more and no less-then how does one characterize a program which demands that we stick to the author's text but not to the author's meaning? Such an interpretive strategy requires that we systematically misread the text.

71. At another point in his article, Perry states that:

if the ratifiers believed that a particular practice violated a constitutional provision . . . a court may not rule that the practice does not violate the provision even if, in the court's view, the practice does not violate the general aspect of the original meaning of the provision. . . .

Id. at 698. Perry, then, apparently advocates Version Three of originalism over Version Four. (He in fact says that Version Three "may make the most sense.") According to Perry, Version Three allows "the development (but not contraction) of the original meaning of a constitutional provision." Id. Perry fails to explain why prohibiting a practice that the ratifiers specifically wished to allow (Version Three) counts as the development of a constitutional provision, while allowing a practice that the ratifiers specifically wished to prohibit (Version Four) counts as a contraction of the original meaning. For instance, to a Kantian retributivist, allowing drawing and quartering (if the moral law demanded this punishment for certain crimes) would obviously count as a development of the Eighth Amendment's meaning.

72. Id. at 709. This will come as a surprise to Professor Monaghan.

73. Id.

74. Id. 
Only a program of systematic misreading allows us simultaneously to retain the author's text and our meaning within the same interpretive matrix. By specifying authorial intent at a level of generality that is nearly meaningless, ${ }^{75}$ the systematic misreader can generate interpretations that are diametrically opposed to the author's meaning, yet claim fidelity to the general principles that must underlie any specific belief.

\section{Ronald Dworkin, Author of "The Constitution"}

When reading the constitutional text leads to unacceptable consequences, Professor Monaghan suggests that we ignore the document, while Professor Perry provides us with a system of almost Ptolemaic complexity ${ }^{76}$ by which we may systematically misread it. In what could perhaps be characterized as the final stage in an evolutionary series of hermeneutical gestures, Ronald Dworkin refuses either selectively to ignore or tentatively to rehabilitate the offending text; instead, he boldly jettisons the object of interpretation altogether. ${ }^{77}$ What Monaghan and Perry only hint at in a partial or indirect fashion, Dworkin asserts in brazenly pragmatic style: ${ }^{78}$ the interpretive dilemma is best solved by severing the Constitution from its authors.

Dworkin considers the possibility of treating the Constitution (or any other statute) as an act of communication, and then rejects this idea, which he calls the "speaker's meaning" theory of interpretation:

The speaker's meaning theory begins in the idea ... that legislation is an act of communication to be understood on the simple model of speaker and audience, so that the commanding question in legislative interpretation is what a particular speaker or group "meant" in some canonical act of utterance. ${ }^{79}$

What counts for Dworkin is not what a statute meant, but rather what it can plausibly be made to mean:

[An ideal judge] interprets not just the statute's text but its life, the process that begins before it becomes law and extends far beyond that moment. He aims to make the best he can of this continuing story, and his interpretation therefore changes as the story develops. He does not identify particular people as the exclusive "framers" of

75. To use Perry's own example: what kind of disfavored government conduct that disproportionately affects a discrete group could not be characterized as a product of "irrational prejudice"? See supra notes 55-56 and accompanying text.

76. Thomas Kuhn has noted the tendency of knowledge paradigms to increase in complexity as they enter the later stages of their life spans. See Thomas KuHN, The STRUCTURE OF SCIENTIFIC REVOLUTIONS, 82-85 (2nd ed. 1970).

77. That is, if we consider the text of the Constitution to be the object of interpretation.

78. Steven Smith has recently argued that, given Dworkin's failure to distinguish his idea of "law as integrity" from straight-forward pragmatism, "an interpretation presenting [Dworkin] as pragmatist is persuasive because that interpretation makes Dworkin the best he can be." Steven Smith, The Pursuit of Pragmatism, 100 YALE L.J. 409, 420 (1990).

79. Ronald DWorkin, LAw's EMPIRE 348 (1986) 
a statute and then attend only to their hopes or expectations or concrete convictions. ... Each of the political considerations he brings to bear on his overall question, how to make the statute's story the best it can be, identifies a variety of people and groups and institutions whose statements or convictions might be relevant in different ways. ${ }^{80}$

For Dworkin, then, the text of a statute is of relatively little importance. The task of the judge is to attach those meanings to the words of a legislative enactment that will make the legislation "the best it can be." The wise judge

interprets history in motion, because the story he must make as good as it can be is the whole story through his decision and beyond. He does not amend out-of-date statutes to suit new times, as the metaphysics of speaker's meaning would suggest. He recognizes what the old statutes have since become. ${ }^{82}$

The question that Dworkin never directly faces (either because of a pragmatic reticence or formalist confusion) ${ }^{83}$ is how old statutes acquire new meanings. If the speaker's meaning does not account for the statute's meaning, then what does? Dworkin's answer appears to be: the interpretive process. ${ }^{84}$ For Dworkin, once the statute has been severed from its author(s), it is free to "enter into new relations" 85 with its interpreters. Their task is then to make the autonomous textual object the best it can be, while taking into account the constraints of history, language, and politics that all interpreters must operate within. ${ }^{86}$

The good interpreter, then, reauthors the statute, jettisoning the offending text and replacing it with a text that makes for a better story. Dworkin's own work provides many enchanting examples of this very process. For instance, the authors of the Fourteenth Amendment wrote:

nor shall any state deprive any person of life, liberty, or property, without due process of law; nor deny to any person within its jurisdiction the equal protection of the laws. ${ }^{87}$

Written by a group of upper-class white males in the middle of the 19th century, this is mere rhetorical praise of formal equality; it does not prohibit segregated schools, ${ }^{88}$ or address the rights of women, ${ }^{89}$ or have

\footnotetext{
80. Id. at $348-49$.

81. Id.

82. Id. at 350 .

83. See supra note 78 ; see also infra note 103 and accompanying text.

84. See generally The Politics of InTERPRetation (W.J.T. Mitchell ed., 1983).

85. See Hans-Georg Gadamer, Truth and Method 357 (Garrett Barden \& John Cumming eds. \& trans., 1975).

86. Those limiting factors generate Dworkin's interpretive principle of "fit." See DwORKIN,

LAW'S EMPIRE, supra note 79, at 230-32.

87. U.S. CONST. amend. XIV, \& 1.

88. See Berger, supra note 7 , at 118-19.
} 
anything to say about matters of sexual preference. ${ }^{90}$

On the other hand, Dworkin's Fourteenth Amendment reads:

nor shall any state deprive any person of life, liberty, or property, without due process of law; nor deny to any person within its jurisdiction the equal protection of the laws. ${ }^{91}$

The contrast is astounding. Dworkin, a contemporary of John Rawls, does not define equality as a series of formal gestures, but as a state in which the sovereign treats each individual with equal concern and respect. ${ }^{92}$ Such an approach clearly prohibits segregated schools. ${ }^{93}$ Nor are women ignored: while the original text speaks of "persons" and sees only men as political actors, Dworkin's text comprehends gender discrimination as a basic affront to the concept of equal protection. ${ }^{94}$ An even more startling contrast is to be found in the attitudes of the two texts to questions of sexual orientation: the 19th-century document completely ignores the issue, while Dworkin's amendment easily encompasses such questions at its core. ${ }^{95}$

Through the process of reauthoring Dworkin offers us an aesthetically pleasing, if complex, ${ }^{96}$ way out of the labyrinth of the classic interpretive conundrum. By detaching the Constitution from its authors, the object of interpretation becomes available for many pleasant procedures that help make it the best Constitution it can be. The good interpreter "recognizes what the old statute [has] since become"; 97 that is, he or she pours the old textual meaning out of the Constitution's linguistic skin and pours in the new wine of enlightened political theory in the form of a reauthored text.

\section{IV}

There is no intellectual exercise which is not ultimately useless. ${ }^{98}$

\section{A. The Empty Idea of Interpretation}

Why must a text mean what its author intends it to mean? After all, Professor Dworkin has observed:

89. See U.S. CoNST. amend. XIX.

90. See Bowers v. Hardwick, 478 U.S. 186, 195 (1986).

91. U.S. CoNST. amend. XIV, § 1 .

92. See JoHN RAWLS, A TheORY OF Justice 511 (1971)

93. See DWORKIN, LAw's EMPIRE, supra note 79, at 360-62.

94. See Ronald Dworkin, Bork the Radical, The New York Review of Books, Aug. 13, 1987 , at 6 .

95. Id. at 6-8.

96. Dworkin's theory requires a judge to employ the "best available political theory" in order to generate the necessary "interpretive fit." See DWORKIN, LAW's EMPIRE, supra note 79, at 230, 350, 380.

97. See supra note 82 and accompanying text.

98. Borges, Pierre Menard, supra note 15, at 43. 
We can understand the equal protection clause as forbidding racial segregation without supposing that any particular historical statesman or draftsman intended that it should do this. We can read Hamlet in a psychodynamic way without supposing that Shakespeare either did or could have intended that we do so. ${ }^{99}$

Now it must be admitted that Dworkin's objection seems intuitively plausible. If we can seem to do these things, what becomes of the claim that a text only means what its author intends? I submit that Dworkin's claim appears to be coherent (let alone plausible) only because we commonly confuse two distinct entities: on the one hand the text, and on the other, the writing within which the text is encoded.

Consider Dworkin's own example. The text of Hamlet is a speech act. It is a communicative gesture or series of gestures by which a certain author expressed a number of thoughts, beliefs, aesthetic impulses, and so forth. Can we read the text of Hamlet as a dramatic commentary on Freud's ideas concerning the Oedipal complex? To do so, we would have to assume that Shakespeare was familiar with Freud's work; otherwise, it would be impossible for the text of the play to make such an implicit allusion. Dworkin believes that an alternative "reading" is possible: we can ignore what Shakespeare meant by the marks that comprise the text of Hamlet, and devise an "interpretation" of those marks which assumes they are making Freudian allusions. While one can readily admit that such a reauthoring of the marks is possible, the question remains, why does such a procedure count as an interpretation of the text of Hamlet? Apparently, Dworkin believes that it does because he fails to make a distinction between a text (the singular speech act of a particular author) and a writing (the particular set of marks which make up a text).

For instance, I could begin an essay on suicide with the words "To be or not to be: that is the question." Yet I clearly am not the author of the first sentence of Hamlet's famous soliloquy. My sentence and Shakespeare's are verbally identical, yet they comprise two separate texts. Although it is logically possible to read Shakespeare's text as if it contained an allusion to my essay, it would be empirically absurd to do so.

The realization that the same set of marks, the same writing, can con-

99. Ronald Dworkin, My Reply to Stanley Fish (and Walter Benn Michaels): Please Don't Talk about Objectivity Any More, in The Politics of INTERPRetation, supra note 84, at 310 . Note that if reading Hamlet's text "in a psychodynamic way" means "reading" it as if it contained a comment on Freud's particular understanding of what he called the Oedipal complex, then Dworkin is advocating reauthoring the text. If Dworkin means reading the text for clues about the author's own psychological state, then he is not primarily interested in the text's semantic meaning, but rather in what indirect evidence the text's meaning provides about Shakespeare's personal psychology. A third possibility is that he means to say we can read Hamlet as containing insights about human psychology that were not yet captured in theoretical form. Although this last alternative is indeed a possible approach to authorial meaning, we should note that no analogous method appears to exist by which we could understand the Equal Protection Clause "in a psychodynamic way," at least for the purposes of legal decisionmaking. 
tain two or more texts solves the puzzle of Dworkin's objection. Once we realize that language is essentially conventional-that nothing exists between the meaning of speech acts and the meaninglessness of marksand that therefore a particular set of marks can mean anything, we will not make Dworkin's mistake of confusing the text with the marks that comprise it.

Another way of characterizing Dworkin's error is to describe it as the imagining of a preinterpretive state where texts exist in temporary autonomy from both author and reader:

Justices who are called liberal and those who are called conservative agree about which words make up the Constitution as a matter of preinterpretive text. ${ }^{100}$

But there can be no preinterpretive text, because even identifying certain words as comprising a particular text-and not some other text which uses the same words ${ }^{101}$-is itself an interpretive act. The mere act of identifying a text as a text requires that we simultaneously identify, on some level, its author(s). ${ }^{102}$

I repeat these points because I am well aware that the idea that a text means only what its author intends it to mean strikes many people as deeply counterintuitive. In our culture we habitually force our ideas about language into an essentially formalist paradigm. ${ }^{103}$ This paradigm produces the fiction of the autonomous text, free from both author and reader, whose very autonomy makes it available for "interpretation," or, more precisely, for the proper "interpretive method." When even as subtle a thinker as Ronald Dworkin routinely conflates the putative object of interpretation (the text of the Constitution, the text of a statute, the text of Hamlet) with the physical marks that encode the interpretive object, it is not surprising that the claim that a text only means what its author intends it to mean seems bizarre, or even dangerous. ${ }^{104}$

At this point, it would be natural for those, like Dworkin, who assert

100. See Dworkin, LAw's EmPIRE, supra note 79, at 358.

101. Hence the distinction between Cervantes' Don Quixote and that of his successor. See supra text accompanying notes $15-23$.

102. Recall that we could not determine if the word real was Spanish or English until we had at least tentatively identified the author. See supra text accompanying note 26.

103. See, for example, Cass Sunstein's recent claims about statutory interpretation: "The words were enacted; the original understanding was not. ... Words have passed through the constitutionally specified mechanisms for enactment of laws; intentions have not, and they are therefore not binding." For Sunstein, it is the autonomous words themselves that bind the legal decisionmaker. Cass Sunstein, After the Rights Revolution 129 (1990).

104. After they initially offered their description of textual interpretation, Knapp and Michaels found themselves accused of, among other things, promoting "an ideology under which a privileged status quo would be secured against fundamental questioning," of creating a rhetorical effect that was "essentially nihilistic," and of clearing the way for "the long-established and well-heeled, native American, fly-by-the-seat-of-one's-pants, critical pragmatists and know-nothings, who have been waiting in the wings ever since the late sixties for such boring annoyances as critical theory, feminism, affirmative action programs, and so forth to disappear." See Knapp \& Michaels, A Reply to Our Critics, supra note 24, at 790, 799. 
that a text can mean things the author never intended it to mean to claim that my account of textual meaning merely splits semantic hairs. I use the term "text" (so this objection would say) in a limited sense: I mean by it roughly what Dworkin means by "speaker's meaning." Those who prefer a hermeneutical approach use "text" to signify both what I have called the text, and what I have termed the writing within which the text is encoded. ${ }^{105}$

Such an objection fails to take into account two related points. First, the statement that a particular account of textual meaning "merely" splits semantic hairs implies that clarification of the terms of debate is not an important function (some modern philosophers would say the most important function) ${ }^{106}$ of intellectual discourse. Identifying just what we are talking about when we talk about texts is a necessary precondition to coherent debate about textual interpretation. The second point follows from the first: if the distinction between a text and a writing is properly maintained, it becomes clear that while one may prefer to deal with a writing rather than with an author's text, it is nevertheless impossible to interpret a writing in the sense one interprets texts.

If a text means what its author intends it to mean, then interpreting a text means, by definition, trying to determine what its author meant. It follows logically that the words that comprise any text could, in principle, mean anything at all (since the meaning of a text is identical to its author's intention, which itself is not bounded), and that no writing could mean anything whatsoever (because the marks themselves, separated from an author's intention, are meaningless). ${ }^{107}$

If this account of textual meaning is correct, two general implications for the interpretive theory of texts follow. The first is that there can be no such theory: that is, there can be no general methodological prescription for how one goes about getting good textual interpretations. In other words, the project of producing a theory (that is, a general method) for determining the best way to read a text becomes empty when we realize that reading a text means trying to figure out what its author intended to say, and nothing more. And this task can't, in the general sense, be theoretical: ${ }^{108}$ it is essentially empirical.

105. This is the approach advocated by Hans-Georg Gadamer. See GADAMER, supra note 85, at 276.

106. Richard Rorty argues that this is the essential feature which marks the later work of Wittgenstein, Heidegger, and Dewey. See Richard RoRTY, PhILOSOPHY AND THE MIRRor OF NATURE 5-13 (1979).

107. That is, they have no meaning as signifiers, in the same sense that the city of Paris or the Grand Canyon have no meaning as signifiers. See THE OXford CoMPANion to THE Mind 383 (R. Gregory ed., 1987):

Some things are about other things: a belief can be about icebergs, but an iceberg is not about anything; an idea can be about the number 7, but the number 7 is not about anything; a book or a film can be about Paris, but Paris is not about anything.

108. That is, in the sense of prescribing a general method of interpretation to the interpreter:

Since there is no limit to what someone can intend something to mean-or, to put this another 
Second, we cannot interpret a writing because a writing, in itself, has no meaning. "Interpreting" the Constitution as a set of marks rather than as a text is identical to "interpreting" the Grand Canyon, or marks made by the desert wind. The Grand Canyon can be made to mean anything at all with equal validity by everyone who views it because, like the physical marks that comprise a writing, it has no a priori meaning. ${ }^{109}$ Considered as a writing the Constitution-like any other writing-means nothing (or, if one prefers, anything) at all. Considered as a text it can mean only one thing: what its authors intended it to mean.

In other words, although we may well disagree about what the author of a text meant, we cannot in any meaningful sense disagree about the best way to interpret a text. Such a disagreement would have significance only if a distinction could be maintained between the meaning of a text and the author's meaning.

\section{B. Is There a Text in this Court?}

Imagine, reader whom I imagine, that you are a practitioner of "constitutional interpretation." If my argument seems plausible then the situation, it must be admitted, appears bleak. On the one hand, the constitutional text has been unmasked as a speech act or acts-that is, as the limited mental product of limited minds: minds limited by the knowledge, the prejudices, the historical circumstances, and the inevitably disappointing capacities ${ }^{110}$ of a certain group of human beings; in other words, by the qualities of the text's authors. On the other hand, the writing which contains the constitutional text offers no help at all to those who believe that law-even constitutional law-should authorize, or constrain, or at least guide the legal decisionmaker.

Even the most passionate proponents of originalism admit that the text of the Constitution is an inadequate source for much of contemporary constitutional law."11 Even the most fervent supporters of "presentminded interpretation" admit that some form of textual constraint must exist in order to give constitutional law legitimacy. ${ }^{112}$ Yet if nothing exists between the inevitable narrowness of the constitutional text and

way, since anyone can use anything to mean anything - there is no point in trying to devise a general interpretive procedure, an interpretive method, that will help resolve interpretive controversies. The object of every interpretive controversy, when it really is an interpretive controversy, is always and only a particular historical fact, and there is no general way to determine what any particular historical fact might be. No general belief, or if one prefers, no theory about the nature of interpretation offers any help in deciding the meaning of any particular text.

Knapp, Practice, Purpose, and Interpretive Controversy, supra note 24, at 1.

109. I use "meaning" here in the limited sense of "semantic meaning." In other words, the Grand Canyon is not a signifier. See supra note 107.

110. For example, we might recall former Justice Thurgood Marshall's refusal to join in the celebrations marking the bicentennial of a text which constitutionalized slavery.

111. See supra notes 41-42 and accompanying text.

112. See DWorkin, LAW's EMPIRE, supra note 79, at 154-60. 
the semantic emptiness of the writing within which that text is encoded, the whole enterprise of contemporary constitutional interpretation would seem to be founded on a mistake. No one, it turns out, actually recommends reading the Constitution: instead we are asked to ignore, or misread, or reauthor that troublesome text.

But where, we might well ask, does this leave the question of legal and political legitimacy? It seems like a strange ritual indeed: our most sacred secular text is continually honored by our cultural rhetoric, as all the while we devise ever more complex strategies for avoiding contact with its meaning.

Now I wish to introduce the following idea. The Constitution is, for the purposes of constitutional adjudication, not a text: it is a sacred, or canonical, writing. That is, it no longer functions primarily as a speech act, but as a cultural artifact which mimics a text and provides occasions for misreading and reauthoring. Sacred and canonical writings are, by their nature, required to perform work within a culture that is beyond the capacities of a mere text, and although they begin their lives as texts-as speech acts-they inevitably become detextualized as they gain sacred or canonical status.

Prime examples of this phenomenon are provided by the Bible ${ }^{113}$ and the works of Shakespeare. Of course the Bible is, within the context of Western culture, the paradigmatic instance of a sacred writing. It is a text which has been all things to all the peoples of our culture and which continues to metamorphose to meet the needs of the present day. Shakespeare, at least to English-speaking peoples, represents the best example of a canonical writer: a man whose writings have achieved such status within his culture that they are analogous to a kind of literary sacred text. When we consider Shakespeare's unmatched position within the hierarchy of secular culture, ${ }^{114}$ it is perhaps not surprising to discover that his texts, too, have been transformed by a multiplicity of "interpretations" into whatever we need them to be. The following examples represent the tiniest fraction of this phenomenon: whole libraries could be, and have been, filled with the products of a cultural imperative that demands of these writings more than any text could possibly give. ${ }^{15}$

113. Several scholars have noted analogies between the rhetoric of constitutional interpretation and the exegesis of religious texts. See generally Robert Burt, Constitutional Law and the Teaching of Parables, 93 Yale L.J. 455 (1983); Thomas Grey, The Constitution as Scripture, 37 STAN. L. REv. 1 (1985); Sanford Levinson, "The Constitution" in American Civil Religion, 1979 SuP. CT. REV. 123.

114. See generally F.E. Halliday, The Cult of Shakespeare (1957).

115. Any human text, that is. The Cabalists developed coherent procedures for dealing with Holy Scripture as an absolute (infinite, infallible, noncontingent) text. They reasoned that chance played no role whatsoever in the production of such a text: everything in it was meaningful, including the number of letters in each word, the letter each word begins with, etc:

Let us suppose that Cervantes was the Holy Spirit (fortunately, he was not, and his work belongs to admirable human texts, imperfect but brilliant creations); then the fact that his book begins $E n$, a monosyllabic word ending in $n$, and that it goes on to another, $u n$, also ending in 
According to Hans Walter Wolff, the multiplicity of the Old Testament texts "resists any principle of exposition which seeks to determine the contents of the texts according to a predetermined schema." 116 John J. Davies believes that the Bible is a unitary text, and can be properly understood only if it is read with its overall unifying schema already in mind. ${ }^{117}$

Edgar McKnight has discovered that the Bible is best interpreted through the lens of modern literary theory; ${ }^{118}$ James Smart asserts with equal vigor that literary theory is useless if one seeks an accurate reading of that text. ${ }^{119}$

Walter Bradley and Roger Olsen, physical scientists and Christian believers, have examined the evidence and concluded that the Creation story told in Genesis is not intended to be taken literally: for them, the text speaks of metaphoric "days" that represent geological epochs. ${ }^{120}$ Henry Morris retorts that the text demands to be taken literally, and that the Genesis story is incoherent unless the word "day" is intended to mean, in this context, the period between the rising and setting of the sun. ${ }^{121}$

Proponents of liberation theology have discovered that the Bible is a product of its socio-historic setting and can only be understood as such. ${ }^{122}$ The Jewish theologian Martin Buber knew that the Bible is "an infinite Book" that contains "eternal reality" in its text. He argued that temporally limited readings obscured or perverted the text's true meaning. ${ }^{123}$

Virginia Mollenkott has affirmed that the Bible reveals God to be an essentially maternal presence in a feminine, nurturing universe. She holds that the Bible is replete with images of a feminine Godhead that protects and comforts Her people. ${ }^{124}$ Phyliss Trible argues that the Biblical text unveils a world of patriarchal terror, where misogyny, rape, and

$n$, and then to lugar (place), a five-letter word, and then to de la (of the) would not have been accidental, because nothing can be accidental in an absolute text.

TWENTy-Four Conversations WITh Borges (Roberto Alifano ed., 1984). Cf. Griswold v. Connecticut, 381 U.S. 479, 484 (1965): "[S]pecific guarantees in the Bill of Rights have penumbras, formed by emanations from those guarantees. ..."

116. Hans Walter Wolff, The Hermeneutics of the Old Testament, in Essays ON OLD Testament HeRmeneutics 160 (Claus Westermann ed., 1979).

117. John J. Davies, Unity of the Bible, in HERMENEUTICS, INERRANCY, AND THE BIBLE 640 (Earl Radmacher \& Robert Preus eds., 1984).

118. Edgar McKnight, Post-Modern USe of The Bible 102-04 (1988).

119. James Smart, The Strange Silence of the Bible in the Church 68-69 (1970).

120. Walter L. Bradley \& Roger Olsen, The Trustworthiness of Scripture in Areas Relating to Natural Science, in HeRMENEUTICS, INERRANCY, AND THE BIBLE, supra note 117, at 283-84.

121. Henry Morris, A Response to 'The Trustworthiness of Scripture in Areas Relating to Natural Science,' in Hermeneutics, INERRANCY, AND THE Bible, supta note 117, at 335.

122. See fernando Belo, A Materialist Reading of the Gospel of Mark (1981).

123. See Martin Buber, Konigtum Gottes 39 (3d ed. 1956).

124. See Virginia Mollenkott, The Divine Feminine: The Biblical Image of God as FEMALE (1983). 
the total subordination of the Feminine are the norms. ${ }^{125}$

These examples, I repeat, represent the merest glimpse of a tiny fraction of some of the conflicting contemporary interpretations brought to bear on the Biblical text. And this amazing heterogeneity of understanding is not a situation peculiar to contemporary readings of the Bible. According to medieval theologians, every passage of Holy Scripture needed to be interpreted in four distinct fashions: literally, morally, allegorically, and anagogically. ${ }^{126}$ This method led, naturally, to an endless series of disputes over the true meaning of key passages in the Biblical text.

A glance at Shakespearean scholarship reveals a similar interpretive situation. For instance, Bernard Grebanier claims that The Merchant of Venice is a sensitive treatment of a moneylender who happens to be a Jew, ${ }^{127}$ while J.L. Cardozo sees the play as an anti-semitic tract. ${ }^{128}$ The distinguished critic Frank Kermode argues that Shylock is the consistent villain of the drama; ${ }^{129}$ his equally distinguished colleague Harold Goddard claims the play's text reveals Shylock to be the essentially innocent victim of his hard-hearted Christian neighbors. ${ }^{130}$

Similar conflicts of understanding are replete in the criticism of every Shakespeare play. For example, Marianne Novy sees in The Taming of the Shrew a celebration of patriarchy; ${ }^{131}$ Coppella Kahn reads that play as a subtle critique of patriarchal practices within marriage. ${ }^{132}$ And when King Lear expires with Cordelia dead in his arms, O.J. Campbell argues that the old king dies of joy, believing Cordelia to be alive. Campbell finds in the text of the play a reassertion of divine justice.

Lear has found in [Cordelia's] unselfish love the one companion who is willing to go up with him ... to the throne of the Everlasting Judge. ${ }^{133}$

James Stampfer draws a different conclusion from the drama's climax:

Even those who have fully repented, done penance, and risen to the tender regard of sainthood can be hunted down, driven insane, and killed by the most agonizing extremes of passion. ${ }^{134}$

Stampfer examines Lear's death and concludes that the text is telling us

125. See Phyliss Trible, Texts of Terror (1984).

126. See St. Thomas Aquinas, Summa Theologica, Part I, Question 1, Article 10.

127. See Bernard Grebanier, The Truth About Shylock (1962).

128. See J.L. Cardozo, The Contemporary Jew in the Elizabethan Drama (1925).

129. See Frank Kermode, Early Shakespeare 224-25 (1961).

130. See Harold Goddard, The Meaning of Shakespeare 111 (1960).

131. See Marianne Novy, Patriarchy and Play in The Taming of the Shrew, in Modern Critical Inter Pretations: The Taming of the Shrew 13 (Harold Bloom ed., 1988).

132. See Coppella Kahn, Title, in MODERn Critical INTERPRETATIONS: The Taming of the Shrew, supra note 131 , at 41 .

133. Q.J. Campbell, The Salvation of Lear, 15 ELH 107 (1948).

134. James Stampfer, The Catharsis of King Lear, 13 ShaKeSPEARE SurveY 4 (1960). 
that "[w]e inhabit an imbecile universe."135 These examples, again, merely scratch the surface. It is safe to say that every well-known passage in any of Shakespeare's plays has generated a multitude of contradictory interpretations. ${ }^{136}$

What special quality or qualities do these texts have that results in this extraordinary interpretive situation? How can different interpreters conclude that the very same words claim that the world is 6,000 and $4,000,000,000$ years old; that the universe is patriarchal and matriarchal; or that there is a supreme moral world order and that we live in a nihilistic void? I submit that it is no quality of the texts themselves, but rather a quality of the interpretive situation into which the texts are subsumed that leads to this endless multiplication of contradictory meanings.

In the case of a sacred writing, the interpretive situation dictates that the holy text remain inerrant, or at least essentially true, in the midst of fundamental cultural shifts concerning questions of religion, morality, science, politics, and so forth. Hence the same words of God have been found to support capitalism and communism, patriarchy and feminism, creationism and evolution, and many more mutually exclusive dialectics within the synthetic conflict that passes for human truth. ${ }^{137}$

A canonical writing fulfills a similar function within the realm of secular culture. Shakespeare is "our" greatest writer: it is only natural that we would find the crucial beliefs and taboos of the contemporary interpretive situation faithfully mirrored in his obliging text. The issues of the moment become, as it were, canon fodder for our "interpretations" of writings which have been granted a kind of sacred place within the current cultural hierarchy. ${ }^{138}$

As a writing becomes sacred or canonical it necessarily absorbs many texts besides that of the author. Today, we can with some effort recover

135. Id. at 10

136. The bibliography of Shakespearean interpretation is so massive that it is unlikely a scholar would be able to read everything written about a single Shakespeare play, even if this were her sole occupation. See 1-22 SHAKESPEARE STUDIES (1969-1990), as a starting point for bibliographical references.

137. A striking illustration of how sacred writings can work purely as cultural artifacts is provided by the Jews of Ethiopia. This religious community was until very recently cut off from the rest of the Jewish world. Nevertheless, they "had the Torah" (the most sacred book in Judaism), and they honored the Hebrew scriptures in their rituals. They were, however, unable to read a single word of the holy texts. See Claire Safran, Secret Exodus 25-28 (1987).

An even more germane example of a cultural artifact's ability to mimic a text is provided by the phenomenon of glossolalia, or "speaking in tongues." Among certain charismatic Christian sects, God manifests Himself by infusing the soul of the believer with the ability to speak in unknown languages. The sacred words uttered under this inspiration are not recognizable as human speech; nevertheless, they can be "interpreted" by the religious community and transformed into meaningful evocations of belief. See generally SPEAKING IN TONGUES: A GUIDE TO RESEARCH ON Glossolalia (Watson E. Mills ed., 1986).

138. See, for example, the battle now being waged over the contents of the cultural canon reflected in such works as Allan BloOM, THE Closing of THE AMERICAN Mind (1987) and E.D. Hirsch, Cultural Literacy: What Every American NeEds to Know (1987). 
pieces of Freud's Shakespeare, ${ }^{139}$ Coleridge's Shakespeare, ${ }^{140}$ Johnson's Shakespeare, ${ }^{141}$ and even Shakespeare's Shakespeare. It is a commonplace to acknowledge that the Bible of the Israelites is not the Bible of the modern Jews, ${ }^{142}$ which in turn is not the Bible of Martin Luther, ${ }^{143}$ which is still less the Bible of St. Thomas Aquinas. ${ }^{144}$

In all these cases, the ineluctable demands of belief required that the author's text give way before the misreadings and reauthorings of different cultures and different times. The protean mutability of these texts blends with the imperishable marks of the writing within which they are encoded to create a cultural icon whose meaning is always changing but whose essence is mystically felt to remain the same. It is this paradoxical quality of the sacred or canonical writing that allows it to produce the cultural cohesion and sense of unity that is beyond the power of any text. And it is this same quality that enables the Constitution to fulfill its function as a unifying cultural artifact-not as a text, but as a canonical writing.

I close this text by answering two imaginary objections by my imaginary reader. The first is of a descriptive nature: perhaps, the argument goes, these baroque speculations have some validity in relation to the Cabalistic jurisprudence of the First, or Eighth, or Fourteenth Amendments, or of the Commerce Clause, but surely we still read the constitutional text when it proclaims that the Senate "shall be composed of two Senators from each State," 145 or that a President "shall hold his office during the term of four years," 146 or that the Twenty-First Amendment repeals the Eighteenth.

I freely admit that we do still read the constitutional text when it proclaims such things; and it is precisely because we still read these clauses (as opposed to ignoring, or misreading, or reauthoring them) that they do not provide occasions for constitutional adjudication and "interpretation." More than one observer has implicitly noted that if it should suddenly become highly desirable, for example, that someone less than thirty-five years old run for President, the relevant portion of the constitutional text might well be jettisoned in favor of whatever ingenious mis-

139. According to Freud, Shylock's character traits are best understood as "the first and most constant results of anal eroticism." 9 THE STANDARD Edition OF THE Complete PSYchological. WORKS OF Sigmund FReUd 171 (1974).

140. See Samuel Taylor Coleridge, Seven Lectures on Shakespeare and Milton (1968); Coleridge on SHAKESPEARE: THE TEXT OF THE LECTURES OF 1811-12 (R.A. Foakes ed., 1971).

141. See Samuel Johnson, Johnson on Shakespeare (Bertrand H. Bronson ed., 1986); Graham F. Parker, Johnson's Shakespeare (1989).

142. See Jacob Mann, The Bible as Read and Preached in the Old Synagogue (1966).

143. See generally Martin Luther, A Commentary on St. Paul's Epistles to the Galatians (N.J. Westwood trans., 1953).

144. See St. Thomas aquinas, ON Law, Morality and Politics (R.J. Regun ed., 1988).

145. U.S. Const., art. I, § 3.

146. U.S.CoNST. art. II, $\S 1$. 
reading will do the necessary "interpretive" work to allow this result. ${ }^{147}$ That is to say, portions of the Constitution are still texts to the extent that they remain irrelevant to the resolution of contemporary cases and controversies.

The second objection is, inevitably, normative. ${ }^{148}$ Fancy ideas about intention and meaning are all very well, objects my well-meaning, wellintentioned, but predictably misguided interlocutor. Yet we chosen ones, ${ }^{149}$ we happy few, ${ }^{150}$ we legal academics, have a special responsibility of awesome dimensions. Our interpretations, especially our constitutional interpretations, march upon "a field of pain and death,"151 and we must therefore always keep in mind that a "false" interpretation is not necessarily a "bad" interpretation. ${ }^{\text {152 }}$ Perhaps if we were to examine the question very closely we would discover that we don't actually advocate reading the Constitution, but might it not be better, after all, to keep this knowledge even from ourselves?

Such an objection makes at least two unwarranted assumptions. It posits, quite unreasonably, that the insights of intellectuals have a regular or predictable impact on the power relations which exist in a culture that routinely ignores them. ${ }^{153}$ And it assumes that the normative implications of this particular insight are self-evident. I believe a text can only mean what its author intends it to mean, but what normative consequences (if any) this belief has for the practice of constitutional interpretation remains unclear. Perhaps if this account of textual meaning were to become widely accepted we would discover that "reading" a canonical writing should involve looking for the best synthesis of the texts it has encompassed. Perhaps some would conclude that a legal document that plays the cultural role assigned to our Constitution must inevitably be read, then misread, then reauthored, and finally rewritten in an interpretive cycle that ends where it began: with an author's newborn text. For my part, I am inclined to accept the tolerant wisdom of an imperial poet:

147. See Peller, supra note 11; Mark Tushnet, $A$ Note on the Revival of Textualism in Constitutional Theory, 58 S. CAL. L. REV. 683-87 (1985); Rapaczynski, The Ninth Amendment and the Unwritten Constitution: The Problems of Constitutional Interpretation, 64 CHI.-KENT L. REV. 177, 194-95 (1988).

148. See Schlag, Normativity and the Politics of Form, supra note 30; see also supra note 30 and accompanying text.

149. Psalms 33:12.

150. William Shakespeare, Henry V, act 4 , sc. 3.

151. Robert Cover, Violence and the Word, 95 YALE L.J. 1601 (1986).

152. See 1 St. Augustine, ON Christian Doctrine § 41:

But anyone who understands in the Scriptures something other than that intended by them is deceived, although they do not lie. However . . . if he is deceived in an interpretation which builds up charity, which is the end of the commandments, he is deceived in the same way as a man who leaves a road by mistake but passes through a field to the same place toward which the road itself leads.

153. For an interesting discussion of the politics of intellectual candor, see Andrew Altman, Beyond Candor, 89 Mich. L. REv. 296, 347.51 (1990). 
There are nine and sixty ways

Of constructing tribal lays

And every single one of them is right. ${ }^{154}$

\section{The End of the World as We Know It}

Those who long for justice require certitude. The intolerable inadequacies of language have been captured by G.K. Chesterton's eloquent words:

Man knows that there are in the soul tints more bewildering, more numberless, and more nameless than the colours of an autumn forest. ... Y Yet he seriously believes that these things can every one of them, in all their tones and semi-tones, in all their blends and unions, be accurately represented by an arbitrary system of grunts and squeals. He believes that an ordinary civilized stockbroker can really produce out of his own inside noises which denote all the mysteries of memory and all the agonies of desire. ${ }^{155}$

It is absurd to imagine that a single instance of human speech, limited by the contingencies of history and pure chance, could demarcate the ultimate boundaries of a people's fundamental law. A text-any text-is subject to the caducity and corruption of all mortal endeavors: the Constitution is not. The constitutional text might be the work of malevolent demiurgi or mere men, but the Constitution itself-protean, unchanging, responsive to our endless needs-could only be the work of a god.

The cold eye of rationalism would mock such assertions, and demand that we face the reality of political choice with no illusions about our ancestors, our texts, or ourselves. Such skepticism fails to reckon with the human need for some semblance of communion with the divine. It laughs at the lines of reverent pilgrims who file past the fading symbols on a piece of parchment that, for them, in some way embodies who they are.

Before we tear the veil of sacredness that obscures a merely human text from our view, we might remember Elijah and Moses, who covered their faces before God; Isaiah, who was terrified when he saw the One whose glory fills the Earth; the rabbi Simeon ben-Azai, who saw Paradise and died; the Midrashim, who will not speak the Shem Hamephorash, the Secret Name of God.

We may choose to utter impious words until the Constitution is nothing but its transitory text; we may reject the seeming absurdities and

154. George Orwell points out that these lines from Kipling were misattributed to Thackeray by John Middleton Murry in Murry's book Adam and Eve. Murry (at that time) was a Marxist who undoubtedly detested Kipling as the ultimate artistic symbol of British imperialism; Murry solved this particular interpretive conundrum with a neat bit of reauthoring. See GeORGE OrWELL, ThE Collected EsSays, Journalism, AND LetTers of GeORGE ORWELl, 193 (S. Orwell \& I. Angus eds., 1968).

155. G.K. Chesterton, G.F. WatTs 44 (1904). 
superstitions of our cultural practices; and we may find that we do not need sacred or canonical writings, and that the constitutional text itself is adequate to our state.

But I suspect that if the Constitution ceases to exist, it will, once again, become necessary to invent it. 